\title{
Atherinella blackburni (Schultz, 1949) at Itamambuca Beach, Ubatuba, SP: ecological characterization and distribution on the Brazilian coast (Teleostei: Atheriniformes: Atherinopsidae)
}

\author{
Mattox, GMT. ${ }^{\mathrm{a}}$, Gondolo, GF. ${ }^{\mathrm{b}}$ and Cunningham, PTM. ${ }^{\mathrm{b}}$ \\ aDepartamento de Zoologia, Instituto de Biociências, Universidade de São Paulo - USP, \\ CP 11461, CEP 05422-970, São Paulo, SP, Brazil

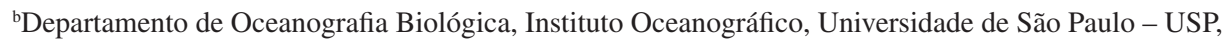 \\ Praça do Oceanográfico, 191, Cidade Universitária, CEP 05508-900, São Paulo, SP, Brazil \\ *e-mail: gmattox@ib.usp.br \\ Received July 7, 2006 - Accepted February 27, 2007 - Distributed May 31, 2008
}

(With 7 figures)

\begin{abstract}
Atherinella blackburni is a silverside species whose occurrence on the Brazilian coast was not properly registered until recently. So far, records of its distribution along the Brazilian shore were limited to Itaparica Island, Bahia State, and Porto Inhaúma, Rio de Janeiro State. In a recent survey of the ichthyofauna of Itamambuca Beach, Ubatuba, São Paulo State, 100 specimens of this species were collected, yielding a considerable source of information regarding its ecology and a new southern limit of its distribution. A detailed survey of an ichthyological collection revealed lots of this species from regions of the Brazilian Northeast, resulting in a northward expansion of the occurrence of A. blackburni in Brazilian waters. Besides the populations found on the Brazilian coast, the species also occurs discontinuously in the Atlantic coasts of Costa Rica, Panama and Venezuela. Meristic and morphometric analysis showed overlapped values between Brazilian populations and the ones closer to the Caribbean. An ecological study of A. blackburni at Itamambuca Beach revealed that it is a predominantly diurnal species with preference for warm and salty waters, often occurring in sandy-bottom environments. It was more abundant in Summer and Winter, when individuals with smaller values of length and weight also occurred.
\end{abstract}

Keywords: ecology, marine fish, new occurrence, silverside, West Atlantic.

\section{Atherinella blackburni (Schultz, 1949) na praia de Itamambuca, Ubatuba, SP: caracterização ecológica e distribuição na costa brasileira (Teleostei: Atheriniformes: Atherinopsidae)}

\section{Resumo}

Atherinella blackburni é uma espécie de peixe-rei cuja ocorrência na costa brasileira não havia sido precisamente registrada até recentemente. Ainda assim, sua distribuição no litoral brasileiro estava restrita à Ilha de Itaparica, Bahia e Porto Inhaúma, Rio de Janeiro. Em um recente levantamento da ictiofauna da Praia de Itamambuca, Ubatuba, São Paulo, foram coletados 100 espécimes desta espécie, originando uma fonte considerável de informações no tocante à sua ecologia e a um novo limite sul de sua distribuição. Um estudo detalhado revelou lotes desta espécie em regiões do nordeste brasileiro em coleção ictiológica, resultando na expansão para o norte da ocorrência de $A$. blackburni em águas brasileiras. Além das populações encontradas na costa brasileira, a espécie também ocorre descontinuamente na costa Atlântica da Costa Rica, Panamá e Venezuela. Análise merística e morfométrica revelou valores sobrepostos entre populações brasileiras e aquelas mais próximas ao Caribe. O estudo ecológico de A. blackburni na Praia de Itamambuca evidenciou que é uma espécie predominantemente diurna com preferência por águas quentes e salgadas, freqüente em ambientes com fundo arenoso. Foi mais abundante no verão e inverno, quando indivíduos com menores valores de comprimento e peso também ocorreram.

Palavras-chave: Atlântico ocidental, ecologia, nova ocorrência, peixe marinho, peixe-rei.

\section{Introduction}

Knowledge of Brazilian marine fishes is not as incomplete as the one of Neotropical freshwater fishes, but much is yet to be done regarding the marine fish fauna on the Brazilian coast (Menezes et al., 2003).
Figueiredo and Menezes (1978) stated that the taxonomy of South American silversides had not been adequately studied and despite of some studies dealing with the taxonomy of higher level taxa in the last 20 years 
(Chernoff, 1986; Dyer and Chernoff, 1996; Dyer, 2006), there are still questions to be pursued at the species level (e.g. Malabarba and Dyer, 2002). The silverside species Atherinella blackburni (Schultz, 1949) well illustrates this issue.

Atherinella blackburni was originally described in the genus Coleotropis based on seven specimens collected in 1925 in the Gulf of Venezuela (Schultz, 1949). Additional collections expanded its area of occurrence, which has a discontinuous distribution between the Caribbean coast of Costa Rica and Porto Inhaúma, Brazil (Gilbert and Caldwell, 1967; Chernoff, 1986; Cervigón, 1991; Aguilera, 1998). The austral limit of the species distribution was registered as the Brazilian Central Coast (Gilbert and Caldwell, 1967), but the exact location of Porto Inhaúma was not explicit. According to J. Williams (pers. comm.), the complete locality of the specimen from Porto Inhaúma is "Bay of Rio, Porto da Inhaúma, Brazil" (22 $52^{\prime} 19^{\prime \prime} \mathrm{S}$ and $\left.43^{\circ} 16^{\prime} 50^{\prime \prime} \mathrm{W}\right)$.

Occurrence of Atherinella blackburni on the Brazilian shore was poorly documented to date. Besides the single specimen from Porto Inhaúma (Gilbert and Caldwell, 1967), only Lopes and Oliveira-Silva (2001) registered its occurrence in Brazilian waters, at Itaparica Island, Bahia State $\left(13^{\circ} 07^{\prime \prime} \mathrm{S}\right.$ and $\left.38^{\circ} 45^{\prime \prime} \mathrm{W}\right)$, based on 29 specimens. These authors briefly discussed their meristic and morphometric data in relation to values from Venezuelan populations given by Gilbert and Caldwell (1967) and attributed the differences found to intra-specific variation.

Despite the high collection effort in many areas of the Brazilian shore, Atherinella blackburni was never among registered species along the coast (e.g., Figueiredo and Menezes, 1978; Giannini and Paiva Filho, 1995; Pessanha et al., 2000; Camargo and Isaac, 2001; Pessanha and Araújo, 2003; Pessanha et al., 2003). Another two species of Atherinopsidae are frequently registered in the Brazilian coast: Odontesthes bonariensis and Atherinella brasiliensis, the latter being the only congener of A. blackburni known in Brazilian waters (Chernoff, 1986; Dyer, 2003).

Several specimens of Atherinella blackburni were collected in a recent survey of the ichthyofauna of Itamambuca Beach, Ubatuba, São Paulo State $\left(23^{\circ} 24^{\prime} \mathrm{S}\right.$ and $45^{\circ} 00^{\prime} \mathrm{W}$ ). This study aims to update the data regarding distribution of A. blackburni on the Brazilian coast, to compare meristic and morphometric data of specimens collected in Brazil with ones from other localities, to present characters diagnosing A. blackburni, and to contribute to the knowledge of its ecology at Itamambuca Beach through a study of its spatial and temporal (diel and seasonal) repartition.

\section{Material and Methods}

A list of all material examined is attached. The majority of material examined in the present study was collected at Itamambuca Beach $\left(23^{\circ} 24^{\prime} \mathrm{S}\right.$ and $\left.45^{\circ} 00^{\prime} \mathrm{W}\right)$ (Figure 1), with permit \#42 from IBAMA (Insituto
Brasileiro do Meio Ambiente e dos Recursos Naturais Renováveis), August 15, 2003.

Five points were selected along the beach (Figure 1) and each one was sampled three times in a 50 meter long transect with a beach-seine measuring $9 \times 1.5 \mathrm{~m}$, $5 \mathrm{~mm}$ of internode distance in the central $3 \mathrm{~m}$-mesh and $15 \mathrm{~mm}$ in the two lateral $3 \mathrm{~m}$-mesh. For standardization purposes collections were made monthly, in full moon periods, at morning and night. Total length (Lt, $\mathrm{mm}$ ) and total weight (Wt, g) was taken from each individual, and then the fishes were fixed in formalin $4 \%$, stored in ethanol $70 \%$ and deposited in the ichthyological collection of Museu de Zoologia da Universidade de São Paulo (MZUSP). The identification was made based on the works of Schultz (1949), Gilbert and Caldwell (1967) and Lopes and Oliveira-Silva (2001).

The ecological study included all specimens collected at Itamambuca Beach $(\mathrm{n}=100)$. Additional material was obtained from Enseada Beach (23 $26^{\prime} 13^{\prime \prime} \mathrm{S}$ and 45 04' 08” W), Ubatuba, São Paulo, in April 2005. For the meristic and morphometric analysis, 69 specimens from Itamambuca Beach were used, 9 from Enseada Beach and 19 from the Brazilian Northeast previously deposited in MZUSP $(n=97)$.

The ecological analysis included relative frequency of numerical abundance and the population structure was based on the average Lt and $\mathrm{Wt}$ at the five collection points, in mornings and nights, along the year. Lt and Wt were taken with an ichthyometer and a digital scale of $0.01 \mathrm{~g}$ precision, respectively. Temperature and salinity were taken with a thermometer and a refractometer, respectively. Counts and measures followed Schultz (1949), Gilbert and Caldwell (1967) and Lopes and Oliveira-Silva (2001). Measures were taken on the left side of the body, whenever possible, with a digital caliper of $0.01 \mathrm{~mm}$ precision. Simple statistical descriptors were obtained for each meristic and morphometric character (i.e., range, average and standard deviation) which were tabled (Table 1) in comparison with data from previous works dealing with this species (Schultz, 1949; Gilbert and Caldwell, 1967; Lopes and Oliveira-Silva, 2001).

\section{Results}

\subsection{Atherinella blackburni (Schultz, 1949) (Figure 2)}

- Coleotropis blackburni Schultz, 1949 [original description, type-locality: Jacuque Point, Gulf of Venezuela, Venezuela]; Gilbert and Caldwell, 1967 [description and comparison with C. starski, occurrence in Costa Rica];

- Coleotropis colecanos Caldwell, 1962 [original description, type-locality: Tortuguero, Costa Rica]; and

- Atherinella blackburni (Schultz, 1949) - Chernoff (1986) [taxonomic account]; Aguilera, 1998 [list of species of Venezuela]; Lopes and Oliveira-Silva, 2001 [description and occurrence at Itaparica 
Island, Brazil]; Dyer, 2003 [list of species of Central and South America].

Diagnosis: Atherinella blackburni can be distinguished from its congener A. brasiliensis by the presence of a scale-sheath along the anal-fin base (vs. scale-sheath absent in A. brasiliensis), more lateral scales in the longitudinal series (44-51, vs. 35-40 in A. brasiliensis), a compressed abdomen (vs. rounded in A. brasiliensis) and by the color pattern, with white body and the distal margin of the caudal-fin black (vs. light-green body and the distal margin of the caudal-fin red in A. brasiliensis). Atherinella blackburni may be distinguished from species of Odontesthes by possessing less gill rakers on the ventral branch of the first gill arch (14-18, vs. 26-38 in Odontesthes) and attaining a smaller body length (102.9 mm, vs. circa of $500 \mathrm{~mm}$ in Odontesthes).

Geographic Distribution: Atherinella blackburni occurs discontinuously in the West Atlantic, on beaches of Costa Rica, Panama, Venezuela and Brazil. In Brazilian waters, the species occurs from Maceió, Alagoas to Ubatuba, São Paulo (Figure 3).

Ecology: In the survey of the ichthyofauna of Itamambuca Beach (Figure 1), 100 individuals of Atherinella blackburni were collected during 13 months, measuring from 24 to $129 \mathrm{~mm} \mathrm{Lt}$ and weighing from 0.33 to $12.67 \mathrm{~g} \mathrm{Wt}$.

Water mass to which Atherinella blackburni was predominantly associated is characterized by high values of temperature and salinity (Figure 4). The species was collected only at Points 1,2 and 3, areas with sandy bottom and little or no influence of freshwater from

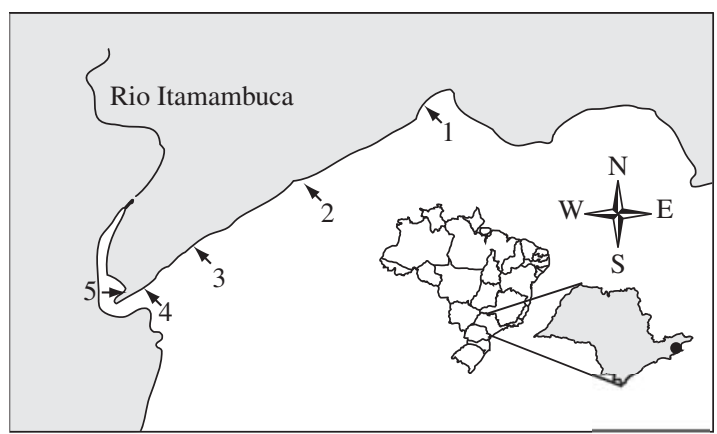

Figure 1. Map with locations of sampling points (numbered 1 to 5) at Itamambuca Beach, Ubatuba, SP (23 $24^{\prime} \mathrm{S}$ and $\left.45^{\circ} 00^{\prime} \mathrm{W}\right)$. Beach length approximately 1800 meters.

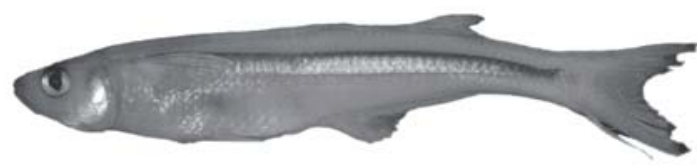

Figure 2. Atherinella blackburni. MZUSP 88689, 102.92 $\mathrm{mm}$ SL.
Rio Itamambuca. Points 4 and 5 were near the mouth of the river and generally had muddy bottom with higher amount of detritus (e.g., shells, plant matter, etc) (Figure 1). Point 2 was the most abundant in number of individuals (Figure 5a), and the smallest specimens occurred in Points 1 and 2 (Figure 6a). The other species in the genus, A. brasiliensis, was the second most abundant in this ichthyological survey (unpubl. data) but did not occur together with $A$. blackburni with the exception of a single specimen from Point 3 in January.

Regarding the temporal repartition in a diel context, there was a higher abundance of individuals in the mornings (Figure 5b), when the smallest individuals in $\mathrm{Lt}$ and $\mathrm{Wt}$ also occurred (Figure 6b). In a seasonal context, Atherinella blackburni was captured throughout the year, except for December, being more abundant in Summer and Winter (Figure 7a). Values of average total length and weight did not vary much throughout the year (Figure $7 \mathrm{~b}$ ) but classes of Lt representing young individuals appeared between January and April.

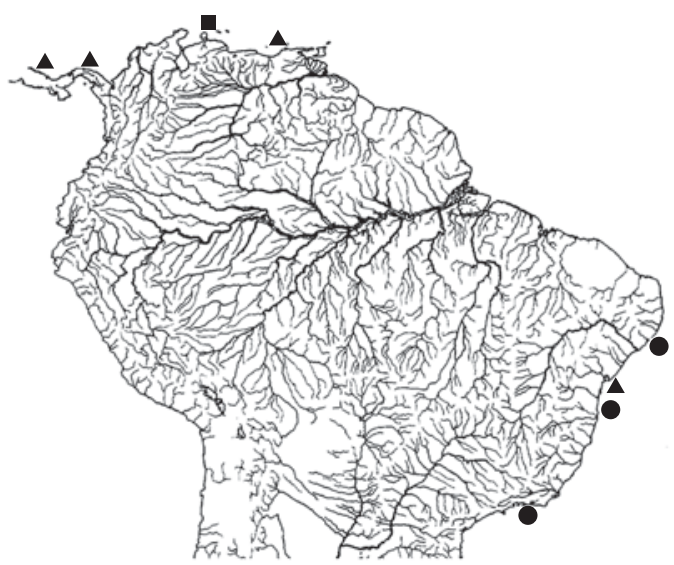

Figure 3. Distribution of Atherinella blackburni along West Atlantic coast. Some marks represent more than one lot. Square represents the type-locality at Jacuque Point, Gulf of Venezuela, triangles correspond to occurrences registered in literature, and circles to localities registered in the present study.

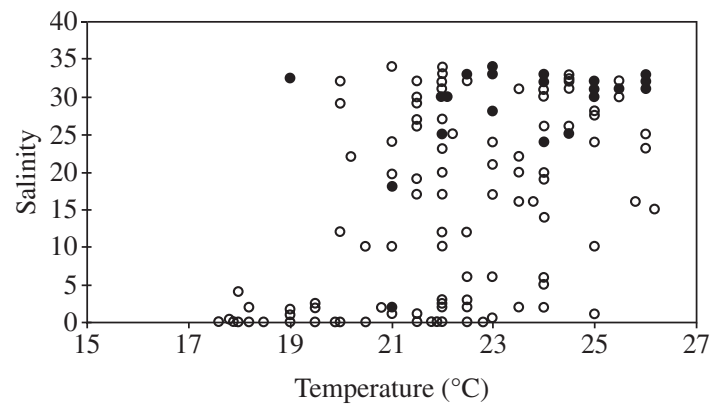

Figure 4. Distribution of temperature and salinity values of the water mass at Itamambuca Beach, Ubatuba, SP. Filled-in circles correspond to points where Atherinella blackburni was registered. 


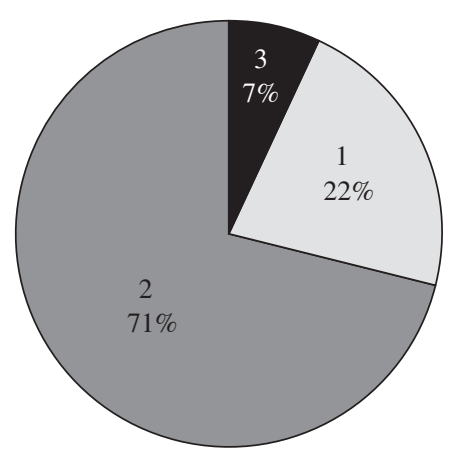

(a)

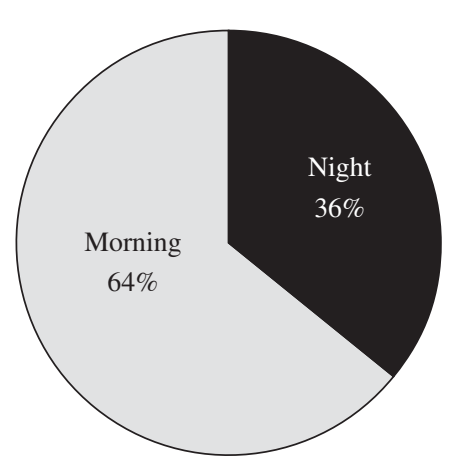

(b)

Figure 5. Distributions of relative frequency of individuals of Atherinella blackburni collected at Itamambuca Beach, Ubatuba, SP in relation to; a) collection points along the beach (it did not occur in points 4 and; 5) and b) periods of the day.
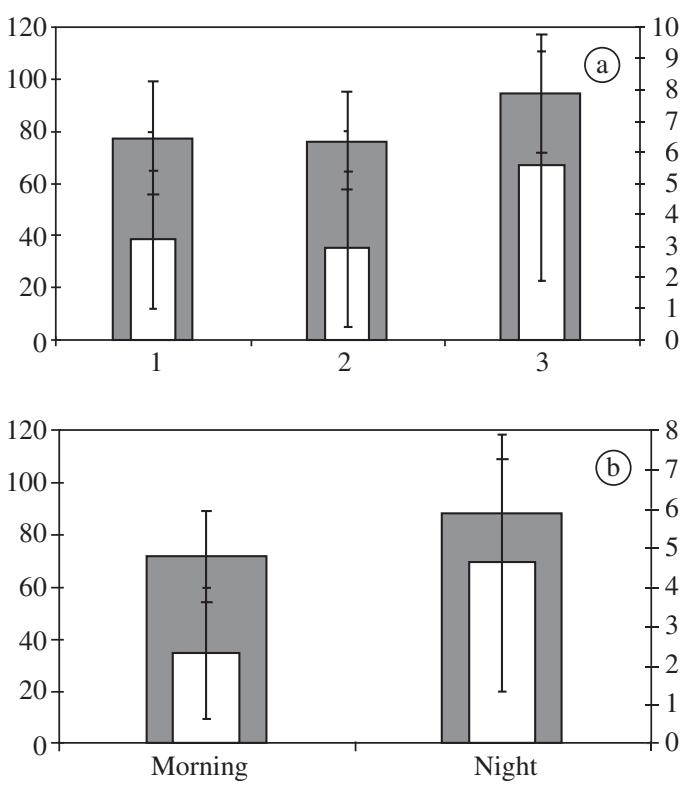

Figure 6. Values of average total length ( $\mathrm{Lt}$ in $\mathrm{mm}$, main axis, grey columns) and average total weight (Wt in g., secondary axis, white columns) of Atherinella blackburni; a) along the collection points; and b) in each diel period at Itamambuca Beach, Ubatuba, SP. Thick standard deviation bars correspond to Lt.
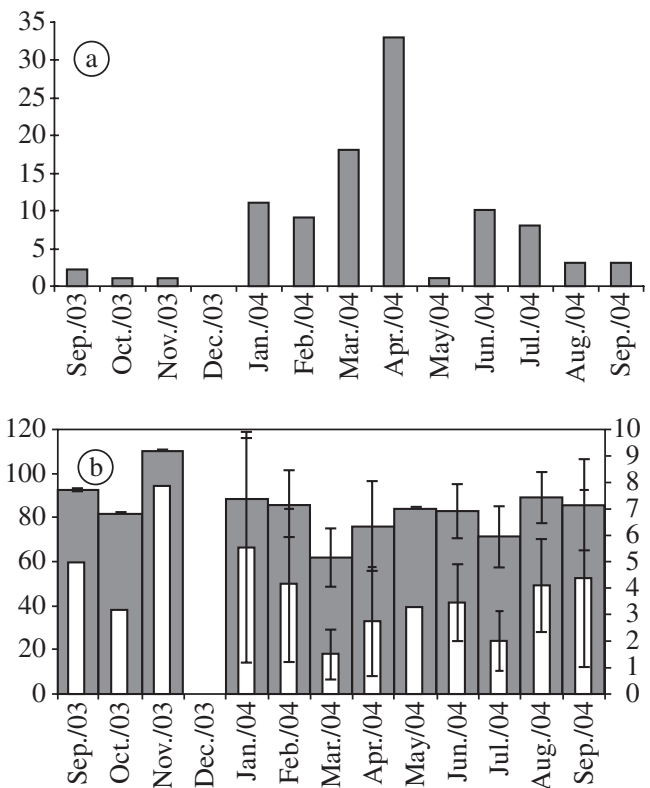

Figure 7. a) Relative numerical abundance of Atherinella blackburni throughout the year at Itamambuca Beach, Ubatuba, $\mathrm{SP}$; b) Values of average total length ( $\mathrm{Lt}$ in $\mathrm{mm}$, main axis, grey columns) and average total weight (Wt in g., secondary axis, white columns) of A. blackburni throughout the year at this beach. Thick standard deviation bars correspond to Lt.

\section{Discussion}

Atherinella blackburni was described in detail in previous studies (Schultz, 1949; Gilbert and Caldwell, 1967; Cervigón, 1991; Lopes and Oliveira-Silva, 2001), therefore it is not redescribed in the present study. Instead, an updated diagnosis for this species in Brazilian waters was provided to aid in its identification. A table is made available (Table 1) with meristic and morphometric values comparing data of the present work with those from the literature.

The present study extended the records of the occurrence of Atherinella blackburni on the Brazilian coast, previously restricted to Porto Inhaúma, Rio de Janeiro (Gilbert and Caldwell, 1967) and to Itaparica Island, Bahia (Lopes and Oliveira-Silva, 2001). Additional material from beaches of Ubatuba and the discovery of specimens from the shores of Alagoas and Bahia States demonstrated that the real distribution of A. blackburni on the Brazilian coast is wider than what was previously registered. Additional collections and the use of more precise characters to identify the species may further expand records of the occurrence of Atherinella blackburni on the Brazilian shore.

Meristic and morphometric analysis revealed an increase in range of many values, probably due to the higher number of specimens sampled in this study in relation to previous works (Schultz, 1949; Gilbert and Caldwell, 1967; Lopes and Oliveira-Silva, 2001). Values presented in these previous works fall within the ranges obtained in the present study (Table 1), not corroborating the intraspecific variations suggested by Lopes and Oliveira-Silva (2001). The only discrepant data given by Lopes and 
Atherinella blackburni: ecology and distribution

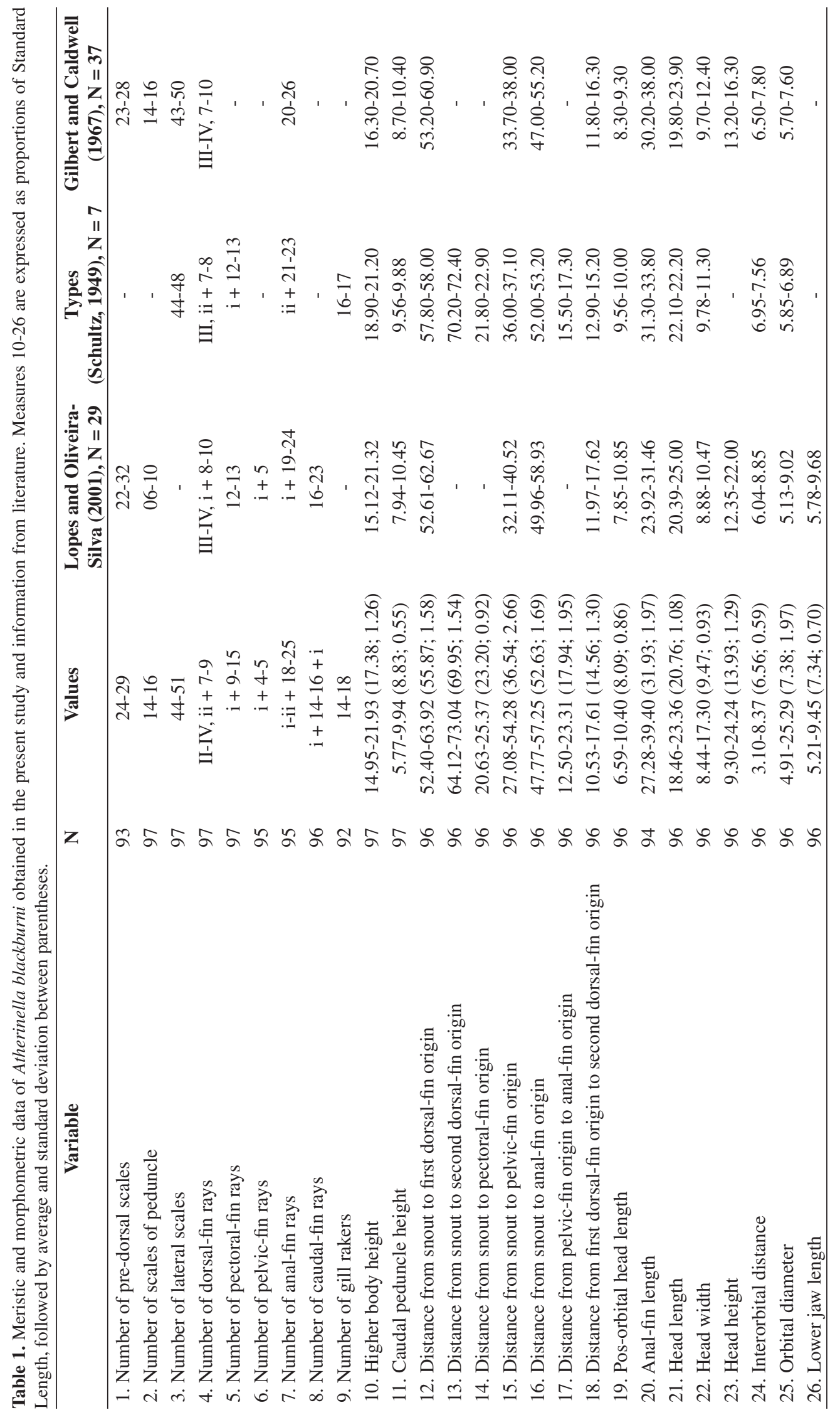


Oliveira-Silva (2001) is the number of scales around the caudal peduncle, and this may be due to a different method these authors might have used to count them (Table 1).

Abundance of small individuals in the months of Summer and Fall indicates that this is the time of year when recruitment occurred. Higher abundance of individuals collected in the mornings may be due to various factors. Patterns of diel activity, according to Reebs (2002), may be extremely plastic and factors such as vulnerability to predators, changes in feeding habits, competition, among others, may be responsible for the choice of which period of the day fish show higher or lower activity patterns.

The ecological evaluation of Atherinella blackburni showed that the species has preference for waters with high temperature and high salinity values (Figure 4) and a sandy bottom. Therefore, it is less generalist than its congener A. brasiliensis, a silverside fish quite common on the Brazilian shore, occurring predominantly in low salinity waters and muddy bottoms, mainly in coastal river mouths (Figueiredo and Menezes, 1978). Environments subject to influence of freshwater and with muddy bottoms seem to restrict A. blackburni occurrence. This ecological repartition between both species of Atherinella was observed in the present study and has been documented before (Cervigón, 1991; Lopes and Oliveira-Silva, 2001).

Discontinuity of the occurrence area of Atherinella blackburni on the Atlantic coast of Central and South America (Chernoff, 1986) (Figure 3) must be further investigated. Based on current knowledge about the ecological features and the species distribution, it is possible to infer that the stocks of populations composed of young and adult individuals may be restricted to sandy beaches along its occurrence area, but the same cannot be affirmed for eggs and larvae without a wider study. Hence, it is suggested that further investigations should be conducted in order to enlighten questions regarding the discontinuous occurrence of A. blackburni on the West Atlantic coast.

Acknowledgements - This work used space and facilities of the DepartamentodeOceanografiaBiológica,Instituto Oceanográfico, USP. The authors are deeply thankful for the support of JL. Figueiredo (MZUSP), who gave access to the collection, helped to identify the specimens and reviewed an earlier draft of the manuscript. M. Toledo-Piza (IB-USP) also gave valuable criticism on the manuscript. P. Lopes (UEFS) and B. Dyer are acknowledged for sending literature. J. Williams (USNM) sent precise information regarding the locality of Porto Inhaúma. The authors would also like to thank all of those who helped in the many field trips during the Itamambuca Ichthyological Survey, especially to TRM. Possato, in memorian.

\section{References}

AGUILERA, OA., 1998. Los peces marinos del occidente de Venezuela. Acta Biol. Venez., vol. 18, no. 3, p. 43-57.

CALDWELL, DK., 1962. A new fish of the genus Coleotropis, family Atherinidae, from Caribbean Costa Rica. Los Angeles County Mus., Contrib. in Sci., vol. 51, p. 1-8.

CAMARGO, M. and ISAAC, V., 2001. Os peixes estuarinos da região norte do Brasil: lista de espécies e considerações sobre sua distribuição geográfica. Bol. Mus. Paran. Emilio Goeldi, Sér. Zool., vol. 17, no. 2, p. 133-157.

CERVIGÓN, F., 1991. Los peces marinos de Venezuela, vol. 1. Fund. Cient. Los Roques. 425 p.

CHERNOFF, B., 1986. Phylogenetic relationships and reclassification of Menidiine silverside fishes with emphasis on the tribe Membradini. Proc. Acad. Nat. Scien. Philadel., vol. 138, no. 1, p. 189-249.

DYER, BS., 2003. Family Atherinopsidae. In REIS, RE., KULLANDER, SO. and FERRARIS-Jr., CJ. Check list of the freshwater fishes of South and Central America. Porto Alegre: Edipucrs. 729 p.

DYER,BS. andCHERNOFF,B., 1996.Phylogeneticrelationships among atheriniform fishes (Teleostei: Atherinomorpha). Zool. J. Linn. Soc., vol. 117, p. 1-69.

DYER, BS., 2006. Systematic revision of the South American silversides (Teleostei, Atheriniformes). Biocell, vol. 30, no. 1, p. $69-88$.

FIGUEIREDO, JL. and MENEZES, NA., 1978. Manual de peixes marinhos do sudeste do Brasil II. Teleostei (1). São Paulo: Museu de Zoologia da Universidade de São Paulo. 110 p.

GIANNINI, R. and PAIVA-FILHO, AM., 1995. Análise comparativa da ictiofauna da zona de arrebentação de praias arenosas do estado de São Paulo, Brasil. Bolm Inst. oceanogr. S Paulo, vol. 43, no. 2, p. 141-152.

GILBERT, CR. and CALDWELL, DK., 1967. The American atherinid fishes of the genus Coleotropis. Los Angeles County Mus. Contrib. in Sci., vol. 125, p. 1-16.

LOPES, PRD. and OLIVEIRA-SILVA, JT., 2001. Registro de Atherinella blackburni (Schultz) (Actinopterygii, Teleostei, Atherinopsidae) na praia de Ponta da Ilha, Ilha de Itaparica, Bahia, Brasil. Revta. Bras. Zool., vol. 18, no. 1, p. 117-122.

MALABARBA, LR. and DYER, BS., 2002. Description of three new species of the genus Odontesthes from the rio Tramandaí drainage, Brazil (Atheriniformes, Atherinopsidae). Ichthyol. Explor. Freshwaters, vol. 13, no. 3, p. 257-272.

MENEZES, NA., BUCKUP, PA., FIGUEIREDO, JL. and MOURA, RL., 2003. Catálogo das espécies de peixes marinhos do Brasil. Museu de Zoologia da Universidade de São Paulo. Conservation International. $160 \mathrm{p}$.

PESSANHA, ALM. and ARAÚJO, FG., 2003. Spatial, temporal and diel variations of fish assemblages at two sandy beaches in the Sepetiba Bay, Rio de Janeiro, Brazil. Estuarine Coastal and Shelf Science, vol. 57, no. 5, p. 817-828.

PESSANHA, ALM., ARAÚJO, FG., AZEVEDO, MCC. and GOMES, ID., 2000. Variações temporais e espaciais na composição e estrutura da comunidade de peixes jovens da Baía de Sepetiba, Rio de Janeiro. Revta. Brasil. Zool., vol. 17, no. 1, p. 251-261.

PESSANHA, ALM., ARAÚJO, FG., AZEVEDO, MCC. and GOMES, ID., 2003. Diel and seasonal changes in the distribution of fish on a southeast Brazil sandy beach. Mar. Biol., vol. 143, no. 6 , p. 1047-1055.

REEBS, SG., 2002. Plasticity of diel and circadian activity rhythms in fishes. Rev. Fish Biol. Fisheries, vol. 12, no. 4, p. 349-371.

SCHULTZ, LP., 1949. A further contribution to the ichthyology of Venezuela. Proc. United States Natl. Mus., vol. 99, no. 3235, $211 \mathrm{p}$. 


\section{Attachment}

List of material examined, organized in alphabetical order of Brazilian states. For each lot, there is the catalog number at Museu de Zoologia da Universidade de São Paulo (MZUSP) followed by number of specimens in each lot, range of standard length in millimeters and locality. Lots with the same locality were grouped.

Alagoas: MZUSP 67169, 3, 42.30-66.54, Avenida Beach in front of AABB; MZUSP 67481, 5, 66.44-77.20, Sobral Beach, Maceió; MZUSP 67484, 5, 26.95-54.60; MZUSP 79894, 4, 38.21-71.88, Avenida Beach, Maceió.
Bahia: MZUSP 67505, 3, 55.01-66.34, Molhado e Molhadinho Beach, Ilhéus. São Paulo: MZUSP 88686, 2 , 75.08-75.18; MZUSP 88687, 1, 66.26; MZUSP 88688, 1, 86.80; MZUSP 88689, 11, 36.40-102.92; MZUSP 88690, 9, 57.12-94.40; MZUSP 88691, 18, 47.69-69.28; MZUSP 88692, 33, 61.20-98.71; MZUSP 88693, 1, 66.27; MZUSP 88694, 10, 44.84-81.16; MZUSP 88695, 8, 38.27-71.65; MZUSP 88696, 3, 59.15-83.62; MZUSP 88697, 3, 52.33-91.67, Itamambuca Beach, Ubatuba; MZUSP 88698, 9, 27.70-61.94, Enseada Beach, Ubatuba. 